\title{
Bacteriological quality of different sources of water in Orathanadu region, Tamil Nadu

\author{
A. Sangeetha, ${ }^{\text {a* }}{ }^{(D)}$ S. Balakrishnan ${ }^{\mathrm{b}}$ and K. Manimaran ${ }^{\mathrm{c}}$
}

${ }^{a}$ Assistant Professor, Department of Veterinary Public Health and Epidemiology, Veterinary College and Research Institute, Orathanadu, Tamil Nadu Veterinary and Animal Sciences University.

bProfessor and Head, Department of Veterinary Public Health and Epidemiology, Veterinary College and Research Institute, Orathanadu, Thanjavur-614625, Tamil Nadu Veterinary and Animal Sciences University

'Associate Professor, Department of Veterinary Public Health and Epidemiology, Veterinary College and Research Institute, Orathanadu, Tamil Nadu Veterinary and Animal Sciences University

Corresponding author: A. Sangeetha | email: girsan81@gmail.com

Co-authors: SB: drbalky@gmail.com ; KM: maranvet@yahoo.com

Received: 09-08-2020, Accepted: 25-09-2020, Published online: 06-10-2020

\begin{abstract}
Safe drinking water is an essential ingredient for good health of both human beings and animals. In developing countries, microbial contaminations of drinking water is a major public health issue and are responsible for causing diarrhea, giardiasis, cholera, salmonellosis, dysentery and gastroenteritis. According to WHO, approximately 1.1 billon people drink unsafe water globally and around $88 \%$ of diarrhoeal diseases reported are caused due to drinking of unsafe water. The objective of this study was to determine the bacteriological quality of different sources of water in Orathanadu, Thanjavur district, Tamil Nadu. A total of 42 water samples were collected randomly from different sources including borewell, pond and supplied municipal water in different regions of Orathanadu, Tamil Nadu and the samples were analyzed for total viable bacterial count and total thermotolerant coliform count. Results suggest that pond water sources were contaminated with thermotolerant coliforms suggesting poor protection and sanitary practices prevailing in the area. This problem can be rectified by constructing feces around water sources, regular maintenance and supervision followed by proper disposal of human and animal wastes are recommended.
\end{abstract}

Keywords: Drinking water, microbial quality, Thermotolerant coliforms, Total viable bacterial count

\footnotetext{
doi: https://doi.org/10.51128/jfas.2020.A006 | How to cite this article: Sangeetha, A., Balakrishnan, S. and Manimaran, K. 2020. Bacteriological quality of different sources of water in Orathanadu region, Tamil Nadu. Journal of Food and Animal Sciences, 01(01): 33-37.

Copyright: Sangeetha et al. Open Access. This article is distributed under the terms of the Creative Commons Attribution 4.0 International License (http://creativecommons.org/licenses/by/4.0/), which permits unrestricted use, distribution, and reproduction in any medium, provided you give appropriate credit to the original author(s) and the source, provide a link to the Creative Commons license, and indicate if changes were made. The Creative Commons Public Domain Dedication waiver (http://creativecommons.org/publicdomain/zero/1.0/) applies to the data made available in this article, unless otherwise stated.
} 


\section{Introduction}

Water is the most important nutrient needed for all metabolic processes essential for life, growth, production and reproduction in humans and animals. However, most of the world's population lacks accesses to adequate and safe water (WHO, 2002). Water could be contaminated by human and animal excreta, lack of personal hygiene, inadequate treatment facilities for waste water (Kuta et al., 2014; WHO, 2011). Microbiological contamination of drinking water is a major public health problem in developing countries. Contaminated water may contain microbial contaminants such as coliforms, $E$. coli, Salmonella, Vibrio cholerae, Yersinia enterolocolitica, Shigella species, Campylobacter species, viruses such as Hepatitis A, Hepatitis E, Rota virus and parasites such as Cryptosporidium parvum and Giardia lamblia (Opara and Nnodim, 2014; Adetunde and Glover, 2010). Presence of coliforms such as Escherichia coli, Klebsiella, and Enterobacter species in water is a possible indicator of the presence of pathogenic organisms (Anyamene and Ojiagu, 2014). These pathogens cause diarrhea, giardiasis, cholera, salmonellosis, dysentery, and gastroenteritis, which is common among the rural dwellers of developing nations (WHO, 2002; Oludairo and Aiyedun, 2016; Aroh et al., 2013). According to WHO, approximately 1.1 billon people drink unsafe water globally and around $88 \%$ of diarrhoeal diseases reported are caused due to drinking of unsafe water (WHO, 2002). Children are most susceptible group of waterborne diarrhoeal diseases and also act as most likely source of infection to others (WHO, 2000).

Routine monitoring of the microbiological quality of water for presence of pathogens is essential to maintain the quality of water. It is impractical to investigate all the bacterial pathogens present in the water. Instead, water can be examined for the presence of fecal indicator organisms such as coliforms. Presence of coliforms in water samples indicates faecal contamination and possible presence of other pathogens (Sindhu et al., 2016). Therefore, the objective of the present study was to investigate the bacteriological quality of different sources of water in Orathanadu, Thanjavur district, Tamil Nadu.

\section{Materials and Methods}

\section{Water Sampling and analysis}

A total of 42 water samples were collected randomly from different sources including borewell (12), pond (5) and supplied municipal water (25) in different regions of Orathanadu, Tamil Nadu. The samples were collected aseptically in sterilized containers and transported to the laboratory without delay.

\section{Bacteriological analysis}

\section{Total Viable Bacterial Count (TVBC) and Total Thermotolerant Coliform Count (TTCC)}

The total viable bacterial count was carried out by the spread plate technique. Water samples were serially diluted up to $10^{-7}$ in sterile phosphate buffered saline and $1 \mathrm{ml}$ from each dilution was pour-plated on the sterile nutrient agar and incubated at $37^{\circ} \mathrm{C}$ for 24 hours. After incubation, total number of colonies was recorded as colony forming unit in per $\mathrm{ml}(\mathrm{CFU} / \mathrm{ml})$. Total thermotolerant coliform count (TCC) of water samples was enumerated using MacConkey agar medium with the incubation temperature of $44^{\circ} \mathrm{C}$ for 24 hours (Banik et al., 2014).

\section{Results and Discussion}

Access to safe and clean water is essential for good health and socio-economic development of human beings. However, contamination of drinking water by human and animal sewage is a major public health concern. According to the World Health Organization, approximately $5 \%$ of all deaths in developing countries are directly related to water diseases arising from poor quality of drinking water (Sindhu et al., 2016). Water diseases resulting in diarrhea are more among children, accounting for $25 \%$ of patientstreated at hospitals and clinics (Steiner et al., 2006). Therefore, it is important to determine the microbial quality of different sources of water consumed by people in Orathanadu region.

In this study, water samples were collected from different sources including borewell (12), pond (5) and supplied municipal water (25) randomly. The collected water samples were analyzed for total viable bacterial count by pour plate technique and total thermotolerant coliform count by plating on nutrient agar and Macconkey agar respectively. The TVBC measures all aerobic bacteria present in the water samples. It was used in late 1800 s to determine the bacteriological quality of water and it is not used nowadays as health related indicator. However, significant changes in TVBC may be used as an alert for possible decline in water quality and further investigation can be done to check the water sources (Bartram et al., 2006). TVBC also used as an indication of potential biofilm formation and its levels in potable 
water should be $<500 \mathrm{CFU} / \mathrm{mL}$. An increase in TVBC $>500 \mathrm{CFU} / \mathrm{mL}(2.7 \log \mathrm{CFU} / \mathrm{mL})$ would indicate a general decrease in water quality and possible biofilm formation in water pipe system which would be hardy difficult to remove by disinfection process (Huang et al., 1995). The total viable bacterial count analyzed for different sources of water is given in the Figure 1. The results suggest that only pond water TVBC level is more than $500 \mathrm{CFU} / \mathrm{mL}$.

Figure 1: Total viable bacterial count of different sources of water samples

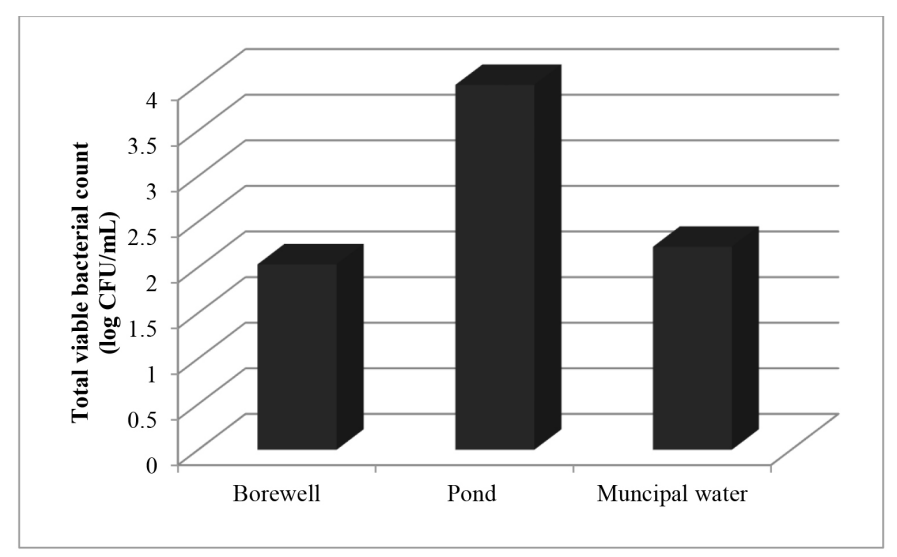

Figure 2: Total thermotolerant coliform count of different sources of water samples

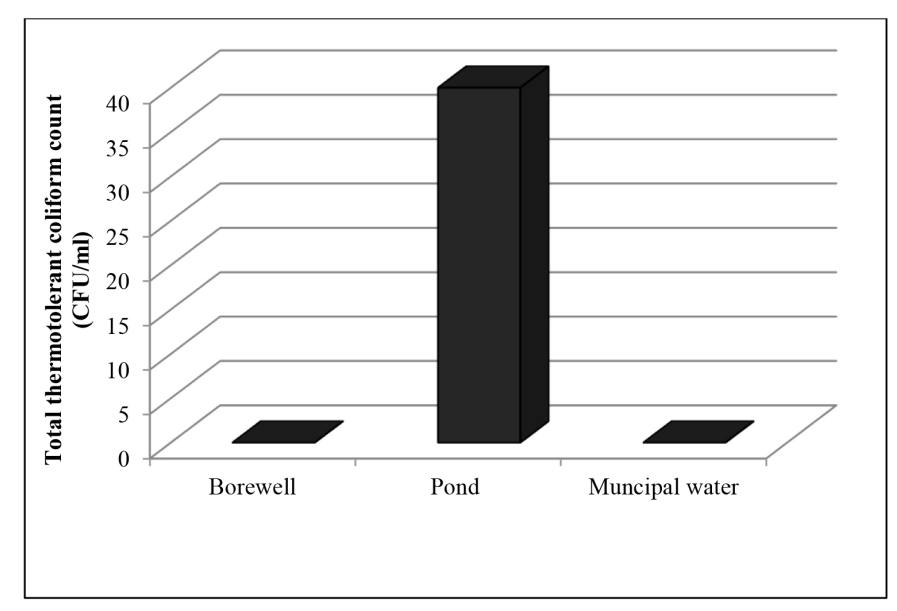

Water quality contamination levels can be tested by detecting total and thermotolerant colifoms. Presence of coliform bacteria is suggestive of breach of sanitary integrity by possible faecal contamination and inadequate treatment (Yasin et al, 2015).The results of total coliform count analyzed for different water sample sources are provided in Figure 2. According to Indian standard (BIS, 2012), total thermotolerant coliform counts shall not be detectable in $100 \mathrm{ml}$ of any two consecutive samples. The result shows that coliforms were not detected in borewell and municipal water sources. However, all the pond water samples were found to be containing thermotolerant coliform higher than Indian acceptable limit. This could be due to mixing of sewage or animal wastes into the ponds and poor personal hygiene. Pond water sources were contaminated with thermotolerant coliforms suggesting poor protection and sanitary practices prevailing in the area. This problem can be rectified by constructing feces around water sources, regular maintenance and supervision followed by proper disposal of human and animal wastes are recommended.

Several studies investigating bacteriological quality of water have been reported previously. A study by Sindhu et al. (2016) determined bacteriological quality of 903 drinking water samples from different schools in Northern India. The study found out that a total of $39.8 \%(360 / 903)$ samples from various sources were found to be unfit for human consumption. Another study by Joseph et al. (2018) assessed bacteriological quality of bottled drinking water available at major transit places in Mangalore city of south India. A total of 24 water bottles of 12 brands were randomly selected to determine total viable count (TVC) and found out that only $62.5 \%$ of samples collected, the bacterial contamination was within acceptable limits certified for drinking purposes. Faecal and total coliform counts of drinking water quality of Ananthanar channel of Kanyakumari district, Tamil Nadu, India was investigated by Antony and Renuga, 2012. The faecal coliform counts varied from 12 to $180 \mathrm{MPN} / 100 \mathrm{ml}$ and E.coli counts ranged from 6 to $161 \mathrm{MPN} / 100 \mathrm{ml}$ for all the sampled sites. Among the total coliforms, Pseudomonas aeruginosa, Shewanella putrefaciens, Klebsiella pneumoniae, Citrobacter freundii and Proteus mirabilis are reported to be present. Tsega et al. (2013) determined bacteriological and physicochemical quality of drinking water sources in a rural community of Ethiopia. Water samples from tap, open springs, open dug wells and protected springs were collected for assessing total coliforms, thermotolerant coliforms, turbidity, $\mathrm{pH}$ and temperature and found out that the most drinking water sources were found to have coliform counts above the recommended national and international guidelines.

\section{Conclusion}

In conclusion, the results of study demonstrated high microbial load of total viable bacterial count and presence of thermotolerant coliforms in pond water in the Orathanadu region. This could be due to poor sanitary practices prevailing in the area. This problem 
can be rectified by constructing feces around water sources, regular maintenance and supervision followed by proper disposal of human and animal wastes are recommended.

\section{Authorship contribution statement}

A. Sangeetha : Conceptualization, Methodology, Formal analysis, Investigation, Writing - original draft, Writing - review \& editing. S. Balakrishnan: Conceptualization, Writing - review \& editing. K. Manimaran: Writing - review \& editing.

\section{Acknowledgments}

All the authors acknowledge and thank their respective Institutes and Universities.

\section{Funding}

No substantial funding to be stated for this work

\section{Declaration of Competing Interest}

All authors declare that there exist no commercial or financial relationships that could, in any way, lead to a potential conflict of interest.

\section{References}

Adetunde, L. and Glover, R.L. 2010. Bacteriological Quality of Borehole Water Used by Students' of University for Development Studies, Navrongo Campus in Upper-East Region of Ghana. Current Research Journal of Biological Sciences. 2(6): 361364.

Antony, R.M. and Renuga, F.B. 2012. Microbiological analysis of drinking water quality of Ananthanar channel of Kanyakumari district, Tamil Nadu, India. Revista Ambiente es Água - An Interdisciplinary Journal of Applied Science. 7(2) 42-48.

Anyamene, N.C. and Ojiagu, D.K. 2014. Bacteriological Analysis of sachet water sold in Akwa Metropolis, Nigeria. International Journal of Agriculture and Biosciences. 3:120-122.

Aroh, K.N., Eze, E.M. and Ukaji, D. et al. 2013. Health and environmental components of sachet water consumption and trade in Aba and Port Harcourt, Nigeria. Journal of Chemical Engineering and Materials Science. 4(2):13-22.

Banik, S.K., Das, K.K. and Uddin, M.A. 2014. Microbiological quality analysis of raw, pasteurized, UHT milk samples collected from different locations in Bangladesh. Stamford Journal of Microbiology. 4(1): 5-8

Bartram, J., Cotruvo, J., Exner, M., Fricker, C., and Glasmacher A, (Eds). 2003. Heterotrophic counts and drinking-water safety: the significance of HPCs for water quality and human health. London, UK: IWA publishing.

Bureau of Indian Standards (IS 10500). 2012. Indian Standard Drinking Water - Specification.

Huang, C.T., Yu, F.P., McFeters, G.A. and Stewart, P.S. 1995. Non-uniform spatial patterns of respiratory activity with biofilms during disinfection. Applied Environmental Microbiology. 61:2252-6.

Joseph, N., Bhat, S., Mahapatra, S., Singh, A., Jain, S., Unissa, A. and Janardhanan, N. 2018. Bacteriological Assessment of Bottled Drinking Water Available at Major Transit Places in Mangalore City of South India. Journal of Environmental and Public Health. Article ID 7472097, 7 pages.

Kuta, G, Emigilati, M., Hassan, A. and Ibrahim, I. 2014. Domestic water sources and its health implication in Lapai Local Government area, Niger State, Nigeria. Ethiopian Journal of Environmental Studies and Management. 7(6):686.

Oludairo, O. and Aiyedun, J. 2016. Contamination of commercially packaged sachet water and the public health implications: an overview. Bangladesh Journal of veterinary medicine. 13(2):73-81.

Opara, A.U. and Nnodim, J. 2014. Prevalence of Bacteria in bottled and sachet water sold in Owerri metropolis. International Journal of Science Innovations and Discoveries. 4: 117-122.

Sidhu, S., Malhotra, S., Devi, P. and Gupta, A. 2016. Bacteriological analysis of the drinking water from different schools in Northern India: A concern in developing countries: International Journal of Medical Research Review. 4(4):630634.

Steiner, T.S., Samie, A. and Guerrant, R.L. 2006. Infectious diarrhea: new pathogens and new challengesin developed and developing areas. Clinical Infectious Disease. 43(4):408-10.

Tsega, N., Sahile, S., Kibret, M. and Abera, B. 2013. Bacteriological and physico-chemical quality of drinking water sources in a rural community of Ethiopia. African Health Sciences. 13(4): 1156- 1161.

World Health Organization/UNICEF. 2000. Global 
Water Supply and Sanitation Assessment Report. Switzerland.

World Health Organization. 2002. The World Health Report. Switzerland: World Health Organization.

World Health Organization /UNICEF. 2010. Rapid assessment drinking water quality in the Federal Democratic Republic of Ethiopia, Country Report of Pilot Project Implementation in 2004-2005. Geneva, New York.

World Health Organization. 2011. Guidelines for Drinking-water Quality. Fourth edition. Geneva, Switzerland.

Yasin, M., T. Ketema and Ketema Bacha. 2015. Physico-chemical and bacteriological quality of drinking water of different sources, Jimma zone, Southwest Ethiopia. BMC Research Notes. 8:541. 